\title{
Improving Social Science Learning Outcomes Through Mimicry- Memorization Method for Class 9.2 Odd Semesters at SMP Negeri 2 Bekasi, Bekasi City
}

\author{
Soelandari ${ }^{a, 1}$ \\ ${ }^{a}$ Social Science Teacher at SMPN 2 Bekasi, Indonesia \\ ${ }^{1}$ Soelandri123@gmail.com
}

\begin{tabular}{ll}
\hline \multicolumn{2}{l}{ Informasi artikel } \\
\hline Sejarah artikel & \\
Diterima & $: 28$ Februari 2019 \\
Revisi & $: 24$ April 2019 \\
Dipublikasikan & $: 3$ Oktober 2019 \\
\hline
\end{tabular}

\section{Kata kunci:}

Motivasi Belajar

Mimicry Memorization

Tindakan Kelas

\begin{abstract}
A B S T R A K
Penelitian ini adalah penelitian tindakan kelas yang bertujuan meningkatkan motivasi belajar peserta didik menggunakan metode MimMem (Mimicry-Memorization Method), yaitu pembelajaran yang mengembangkan cara untuk meniru dan menghafal secara aktif Oleh peserta didik. Penelitian tindakan ini terdiri dari tiga siklus. Pada siklus I hasil prestasi belajar siswa secara rata rata sebesar 63.09 (63\%). Karena masih berada dibawah KKM yang ditentukan sebesar 70 persen, maka dilanjutkan kegiatan siklus ke II. Pada siklus II ini, rata-rata skor penguasaan siswa semakin meningkat, dengan rata-rata nilai 66,92. Namun nilai tersebut masih dibawah standar, sehingga dilanjutkan dengan kegiatan siklus ke III. Pada siklus ini, hasil prestasi belajar siswa secara rata rata sebesar 78.65 (79 persen). Karena sudah berada diatas nilai standar yang ditentukan. Maka tidak dilakukan dilakukan kegiatan siklus berikutnya. Sehingga penggunaan metode Mim-Mem (Mimicry-Memorization) dalam penelitian dinyatakan berhasil meningkatkan motivasi dan hasil belajar peserta didik.
\end{abstract}

\section{Keywords:}

Learning motivation

Mimicry Memorization

Class Action

\begin{abstract}
A B S T R A C T
This research is a classroom action research that aims to improve students' learning motivation using the Mim-Memorization Method, which is the method that develops ways to imitate and memorize actively by students. This action research consisted of three cycles. In the first cycle student learning outcomes on average by 63.09 (63\%). However, it is still specified standard score (KKM) of 70 percent, as a result the cycle II activities will continue. In this second cycle, the average student mastery score increased, but still below the standard with an average score of 66.92. So it is continued with the third cycle. In this cycle, the average student achievement is 78.65 (79 percent). As it is above the specified standard score (KKM) already, the cycle is stopped. To sump up, MimicryMemorization method is successful in increasing students' motivation and learning outcomes.
\end{abstract}

\section{Introduction}

Education strongly determines the life quality of a nation. The role of education is crucial to develop a good character of human resources (Karsidi, 2005). As a result, it will create an intelligent, peaceful, open, and democratic life. Education is one of the supporting factors for the progress of the whole nation to achieve the development goals, namely towards justice, and prosperous society, both material and spiritual based on Pancasila (Widodo, 2015). In addition, education has developed to provide basic needs such as clothing, food, housing, and health needs (Policy for Sida's Development Cooperation, 2001).

Nowadays, everyone is generally aware of the importance of education, both for personal development and for the progress of the nation and state. The efforts to improve the quality of education have been carried out by the Indonesian ancestors for a long time. However, until now, the results have not been 
satisfactory. It is proven by the facts as follows: (1) there are $75 \%$ of educational services in Indonesia do not meet minimum service standards, (2) Indonesia's access and quality of education in 2013 - 2014 shows that Indonesia is at ranked 40th out of 40 countries which means at the bottom, (3) for higher education only ranked 40 out of 50 states, (4) and for literacy skills; in the mapping of science and mathematics shows that Indonesia children are in position 40 out of 42 countries (Widodo, 2015).

Education is a process of human development that lasts a lifetime. Social Sciences, which are taught in schools, have an essential role in providing opportunities for students to involve directly in a variety of learning experiences, which are chosen systematically.

Social Sciences aims that students have the following abilities.

1. Develop assessment skills associated with a method, technique and learning strategy, to obtain the expected learning outcomes

2. Improving social science learning achievement through a process of assessment

3. Improve the critical thinking skills

4. Laying the foundation of a strong moral character through identifying the order of the laws and regulations of the national law contained in the Social Sciences.

5. Developing sportsmanship, honesty, discipline, responsibility, cooperation, confidence and democracy

6. Developing skills to maintain the welfare of ourselves, others, and the environment related to identifying the order of national legislation that is contained in Social Sciences

7. Understanding the concept of Social Sciences activities in a clean environment as information to achieve comprehensive learning, learning system, skilled, and have a positive attitude.

According to Suryabrata cited by Muhari (1983: 25), learning achievement is the last learning outcome achieved as well as possible in a particular time in school. Soemarsono (1986: 18) defines learning achievement is a value that embodies student learning outcomes achieved according to his ability to do the task at a particular time.

Based on the opinions above, the author concludes that: (1) Learning achievement is a form of learning outcomes achieved by students after they carry out learning activities in school. (2) The learning outcomes achieved by students according to their abilities, both intellectual and non-intellectual skills. (3) Student learning effort is a process that is influenced by many factors, including the use of media that is relevant to students' uniqueness and learning environment. (4) To asses, the learning outcomes of students at school, evaluation of learning is conducted.

Modern education experts formulate the act of learning is a form of growth or change in a person expressed in new ways of behavior, which is resulted from practice and experience (Zainal Aqib, 2002). Ernest R Hilgard further explains it in his book "Theories of Learning." He told that "Learning is the process by which an activity originates or is changed through training products (whether in the laboratory or the natural environment) at distinguished from the changes by factors not attribute able to training."

Motivation is a change in energy of a person which is marked by the emergence of feelings and reactions to achieve goals (Tohid \& Jabbari, 2012). Alternatively, motivation is the urge to carry out learning activities, both from within someone (intrinsic) and from outside oneself (extrinsic) - motivation functions as an impetus, director, and driver of behavior (Roland, 2003). Motivation also has value in 
determining success, democratizing education, fostering creativity, and determining the effectiveness of learning. Generally, motivation is a reason or urge for someone to act.

\section{Method}

This research was Classroom Action Research (CAR), which carried out with stages of the recycling cycle. Arikunto (2009: 74) states that CAR includes (a) action planning, (b) action implementation, (c) observation and, (d) reflection.

1. Cycle I
a. Initial Reflection
b. Planning (preparation before teaching, teaching and learning activities, assessment procedures)

2. Cycle II

Reflection cycle I
a. Action Planning
b. Action Implementation
c. Evaluation / Reflection

The research data was obtained by preparing an observation sheet. The assessment aspects used include:

a. The assessment for the essay assignment seeks understanding in describing the diversity of the shape of the earth, its process of formation, and its impact on life. from internet sites.

b. Rating is based on the following assessment rubric.

1) Students are declared successful if their level of achievement with SKBM 6.5 (65\%)

2) Provide a remedial program for students whose achievement level is less than $65 \%$

3) Provide enrichment programs for students whose achievement level is more than $65 \%$

4) The results of the assessment are entered into the cognitive assessment sheet.
Table 1. Cognitive Assessment Sheet

\begin{tabular}{lllllll}
\hline \multirow{2}{*}{ No Name } & \multicolumn{4}{l}{ Question Number } & Skor & Ket \\
\cline { 2 - 5 } & 1 & 2 & 3 & 4 & & \\
\hline 1 & & & & & \\
\hline 2 & & & & & \\
\hline 3 & & & & & \\
\hline etc & & & & & \\
\hline
\end{tabular}

Information:

\begin{tabular}{clc}
\hline No & \multicolumn{1}{c}{ Rated Aspect } & Score \\
\hline 1 & Student answers are incorrect & $0-25$ \\
\hline 2 & $\begin{array}{l}\text { Student answers are } \\
\text { incomplete but correct }\end{array}$ & $26-75$ \\
\hline 3 & $\begin{array}{l}\text { Students answers are complete } \\
\text { and correct }\end{array}$ & $76-100$ \\
\hline
\end{tabular}

Students were assessed cognitive aspects and affective aspects. The activities of the students were observed according to the following assessment sheet:

Table 2. Affective Assessment Sheet

\begin{tabular}{cll}
\hline \multirow{2}{*}{ No } & \multicolumn{1}{c}{ Statement } & \multicolumn{1}{c}{ Activity } \\
\cline { 2 - 3 } 1 & $\begin{array}{l}\text { Students attend Social } \\
\text { Sciences lessons }\end{array}$ \\
\hline 2 & $\begin{array}{l}\text { Students feel happy with the } \\
\text { teaching of Social Sciences }\end{array}$ \\
\hline 3 & $\begin{array}{l}\text { Students ask the teacher if } \\
\text { there is anything unclear }\end{array}$ \\
\hline 4 & $\begin{array}{l}\text { Students assignments on } \\
\text { time }\end{array}$ \\
\hline 5 & $\begin{array}{l}\text { Students always work on } \\
\text { practice questions }\end{array}$ \\
\hline 6 & $\begin{array}{l}\text { Students try to have Social } \\
\text { Sciences textbooks }\end{array}$ \\
\hline 7 & $\begin{array}{l}\text { Students try to find } \\
\text { references }\end{array}$ \\
\hline 8 & $\begin{array}{l}\text { Students discuss with each } \\
\text { other in solving learning } \\
\text { material }\end{array}$ \\
\hline
\end{tabular}




\begin{tabular}{|c|c|c|c|}
\hline \multirow{2}{*}{ No } & \multirow{2}{*}{ Statement } & \multicolumn{2}{|c|}{ Activity } \\
\hline & & Yes & No \\
\hline 9 & Students always ask & & \\
\hline & questions to the teacher & & \\
\hline 10 & $\begin{array}{l}\text { Students always receive } \\
\text { answers in solving learning } \\
\text { materials both form the } \\
\text { teacher and fellow students }\end{array}$ & & \\
\hline
\end{tabular}

The assessment of students' assignments in the form of essays will be assessed using an assessment rubric as below:

Table 3. Students Activity Rubric

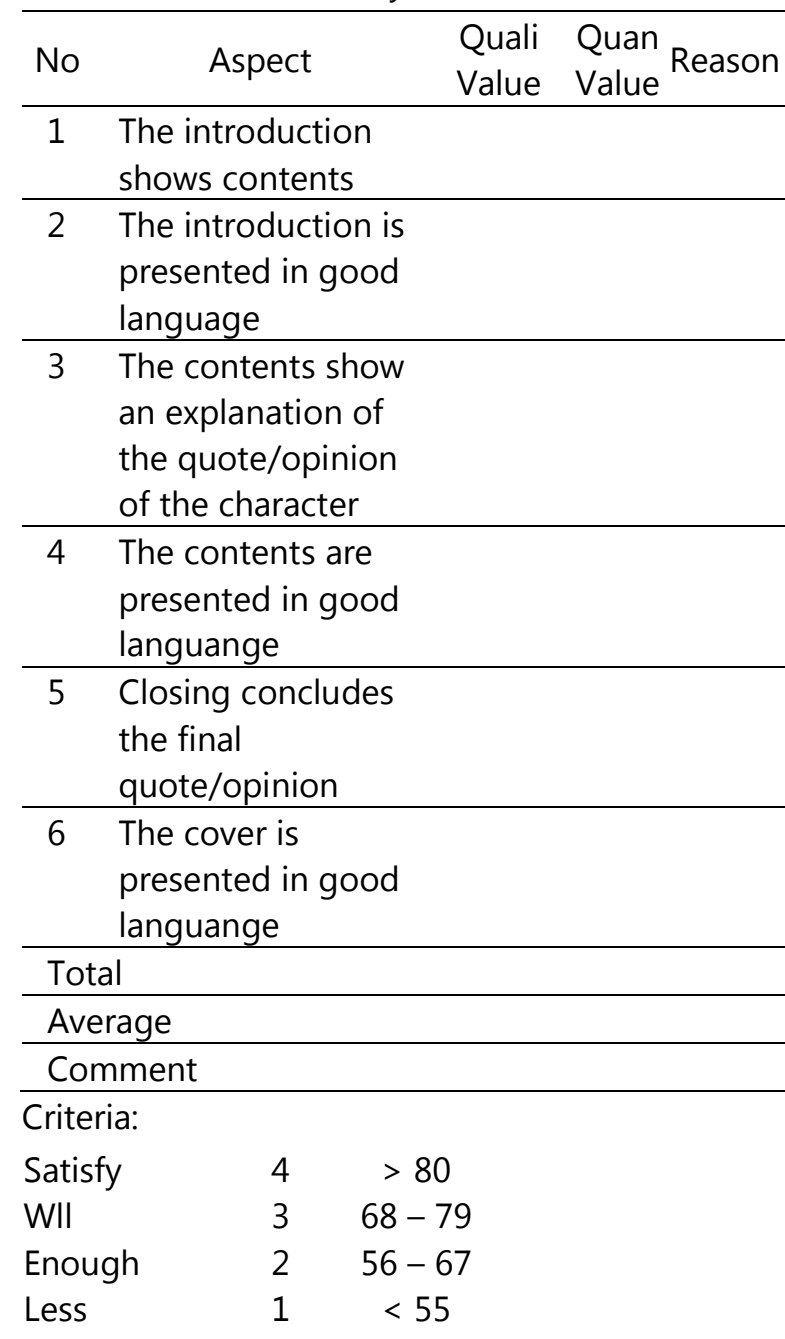

\section{Result and Discussion}

This research is planned to be two cycles, each of which will be elaborated starting from preparation (1) planning; (2) implementation; (3) observation; and (4) reflection. Students are given an assignment before taking action, while the results of this initial test show that the student's score is at 50.83 of 100 . If the student mastery score is included in the categories that have been compiled, then a distribution like seen in table 4 . In table 4 obtained that 49 students who took the test at the end of the first cycle, there were 18 people (36.73\%) obtained mastery scores of less than 65 and 31 people (63.27).

Table 4. Cycle I Value of Learning Outcomes

\begin{tabular}{|c|c|c|}
\hline No & Name & Scores \\
\hline 1 & Adelia Wulan Sari & 66 \\
\hline 2 & Adib Budi Darma & 63 \\
\hline 3 & Afifa Salsabila Febiani & 62 \\
\hline 4 & Aisyah Tatsbiita & 65 \\
\hline 5 & Aji Linungit Saduro & 66 \\
\hline 6 & Andi Pebrianto & 61 \\
\hline 7 & Antika Lestari & 60 \\
\hline 8 & Arga Eryzal Pradinata & 64 \\
\hline 9 & Ary Rachman Saleh & 63 \\
\hline 10 & Arya Muhamad & 62 \\
\hline 11 & Astri Purwandari & 65 \\
\hline 12 & Berliana Desi & 66 \\
\hline 13 & Delvindiaz Ridho & 61 \\
\hline 14 & Dheka Agustin & 60 \\
\hline 15 & Eka Ayu Susanti & 64 \\
\hline 16 & Essa Bagus Kurniawan & 63 \\
\hline 17 & Iis Sandy Setyorini & 65 \\
\hline 18 & Lia Susanti & 66 \\
\hline 19 & Muhammad Sena & 61 \\
\hline 20 & Nadhieva Avionyta & 60 \\
\hline 21 & Nayla Sabrina Haura & 64 \\
\hline 22 & Rahma Ivena Larissa & 63 \\
\hline 23 & Rizki Amelia Putri & 62 \\
\hline 24 & Salma Nur Anisya & 65 \\
\hline 25 & Silvia Ardisty & 66 \\
\hline 26 & Sita Fara Yunanda & 61 \\
\hline 27 & Tesalonika Berthania & 60 \\
\hline 28 & Ulfah Inaz Anisayahya & 64 \\
\hline 29 & Wahlia Winduniar & 66 \\
\hline 30 & Wendi Satria Santosa & 61 \\
\hline 31 & Wahyu Indah S & 60 \\
\hline 32 & Wulan Sari & 64 \\
\hline \multicolumn{2}{|c|}{ Total } & 2019 \\
\hline
\end{tabular}




\begin{tabular}{ll}
\hline No Name & Scores \\
\hline Average & 63.09 \\
\hline Percentage & $63 \%$
\end{tabular}

Source: Research, 2018

The results of the assignments given to students in table 4 show the results of student achievement on average of 63.09 (63\%). Because it is still below the specified standard score $(\mathrm{KKM})$ of $70(70 \%)$, after reflection, some things need to be added in the teaching and learning process. Therefore, this research needs to be done in Cycle II. In the second cycle, the mastery score is still below the standard with an average of students getting a score of 65.15 . The results of this value are still below the predetermined scores of 70 . However, the students' scores in the second cycle have been increased compared to the activities of the first cycle. After reflection, it is necessary to carry out the third cycle. The results of the second cycle can be seen in table 5 .

Table 5. Cycle II Learning Outcomes

\begin{tabular}{lll}
\hline No & Name & Scores \\
\hline 1 & Adelia Wulan Sari & 66 \\
\hline 2 & Adib Budi Darma & 64 \\
\hline 3 & Afifa Salsabila Febiani & 65 \\
\hline 4 & Aisyah Tatsbiita & 64 \\
\hline 5 & Aji Linungit Saduro & 65 \\
\hline 6 & Andi Pebrianto & 66 \\
\hline 7 & Antika Lestari & 67 \\
\hline 8 & Arga Eryzal Pradinata & 68 \\
\hline 9 & Ary Rachman Saleh & 62 \\
\hline 10 & Arya Muhamad & 63 \\
\hline 11 & Astri Purwandari & 64 \\
\hline 12 & Berliana Desi & 65 \\
\hline 13 & Delvindiaz Ridho & 64 \\
\hline 14 & Dheka Agustin & 65 \\
\hline 15 & Eka Ayu Susanti & 66 \\
\hline 16 & Essa Bagus Kurniawan & 67 \\
\hline 17 & Iis Sandy Setyorini & 68 \\
\hline 18 & Lia Susanti & 62 \\
\hline 19 & Muhammad Sena & 64 \\
\hline 20 & Nadhieva Avionyta & 65 \\
\hline & & \\
\hline
\end{tabular}

\begin{tabular}{lll}
\hline 21 & Nayla Sabrina Haura & 66 \\
\hline 22 & Rahma Ivena Larissa & 67 \\
\hline 23 & Rizki Amelia Putri & 68 \\
\hline 24 & Salma Nur Anisya & 62 \\
\hline 25 & Silvia Ardisty & 63 \\
\hline 26 & Sita Fara Yunanda & 64 \\
\hline 27 & Tesalonika Berthania & 65 \\
\hline 28 & Ulfah Inaz Anisayahya & 64 \\
\hline 29 & Wahlia Winduniar & 65 \\
\hline 30 & Wendi Satria Santosa & 66 \\
\hline 31 & Wahyu Indah S & 67 \\
\hline 32 & Wulan Sari & 68 \\
\hline Total & 2085 \\
\hline Average & 65.15 \\
\hline Percentage & $65 \%$ \\
\hline
\end{tabular}

Source: Research, 2018

Learning activities in the third cycle are more emphasized materials related to the diversity of the shape of the earth, the process of formation, and its impact on life. As for the third cycle, the student learning outcomes have met the standard scores with an average score of 78.65 or 79 percent. Thus the next cycle of activities are not necessary. These are learning outcomes of students in the third cycle.

Table 6. Cycle III Learning Outcomes

\begin{tabular}{llc}
\hline No & Name & Scores \\
\hline 1 & Adelia Wulan Sari & 74 \\
\hline 2 & Adib Budi Darma & 77 \\
\hline 3 & Afifa Salsabila Febiani & 78 \\
\hline 4 & Aisyah Tatsbiita Nisaa'ul & 76 \\
\hline 5 & Aji Linungit Saduro & 77 \\
\hline 6 & Andi Pebrianto & 79 \\
\hline 7 & Antika Lestari & 80 \\
\hline 8 & Arga Eryzal Pradinata & 82 \\
\hline 9 & Ary Rachman Saleh & 78 \\
\hline 10 & Arya Muhamad Bimantara & 79 \\
\hline 11 & Astri Purwandari & 81 \\
\hline 12 & Berliana Desi Ramadhani & 83 \\
\hline 13 & Delvindiaz Ridho & 76 \\
\hline 14 & Dheka Agustin Prasetyowati & 77 \\
\hline 15 & Eka Ayu Susanti & 78 \\
\hline 16 & Essa Bagus Kurniawan & 76 \\
\hline 17 & Iis Sandy Setyorini & 77 \\
\hline 18 & Lia Susanti & 79 \\
\hline
\end{tabular}




\begin{tabular}{llc}
\hline No & Name & Scores \\
\hline 19 & Muhammad Sena & 80 \\
\hline 20 & Nadhieva Avionyta & 82 \\
\hline 21 & Nayla Sabrina Haura Syada & 78 \\
\hline 22 & Rahma Ivena Larissa Asianti & 79 \\
\hline 23 & Rizki Amelia Putri & 81 \\
\hline 24 & Salma Nur Anisya & 83 \\
\hline 25 & Silvia Ardisty & 76 \\
\hline 26 & Sita Fara Yunanda & 76 \\
\hline 27 & Tesalonika Berthania Putri & 77 \\
\hline 28 & Ulfah Inaz Anisayahya & 79 \\
\hline 29 & Wahlia Winduniar Nilam & 80 \\
\hline 30 & Sari & 82 \\
\hline 31 & Wendi Satria Santosa & 78 \\
\hline 32 & Wulan Sari & 79 \\
\hline Total & 2517 \\
\hline Average & 78.65 \\
\hline Percentage & $79 \%$ \\
\hline
\end{tabular}

Source: Research, 2018

\section{Conclusion}

The learning process is an activity that must not be separated between one activity with the next learning activity. It should be the teacher's attention that students are considered to learn if they have experienced the process.

The increased student mastery in the first cycle has shown knowledge has increased, but still needs to be improved. It can be concluded that the results of student achievement are, on average, 63.09 (63\%) because it is still below the specified standard score (KKM) of 70 (70\%). So this research needs to be done on the second cycle. In this second cycle, the results of student achievement are on average by 65.15 (65\%). Because it is still below the KKM of $70(70 \%)$, so this research needs to be done on the third cycle. in this third cycle, on average 78.65 (79\%) because it is still above the KKM of 70 (70\%). So this research is stopped. So that in the research has been successful and ompleted.

\section{References}

Aqib, Zainal. 2002. Profesionalisme Guru dalam Pembelajaran. Surabaya: Insan Cendekia.

Ari K, Suharsimi. 2009. Penilitian Tindakan Kelas, Jakarta: Bina Aksara.
Badan Standar Nasional Pendidikan. 2009. Permen 22 tahun 2009 tentang Standar Kompetensi dan Kompetensi Dasar Mata Pelajaran Ilmu Pengetahuan SosialSD / MI, Jakarta.

Departemen Pendidikan Nasional. 2003. Kurikulum 2004 Standar Kompetensi Mata Pelajaran IImu Pengetahuan Sosial Sekolah Dasar dan Madrasah Ibtidaiyah, Jakarta

Direktorat Profesi Pendidik. 2009. Pedoman Pelaksanaan Pemberian Block Grant Kegiatan Pengembangan Profesi Guru Berupa Pelatihan Tindakan Kelas. Jakarta

Karsidi, R., 2005. Sosiologi Pendidikan. Solo: UNS Press.

Policy for Sida's Development Cooperation, 2001. Education for All: A Human Right and Basic Need. Gothenburg: Elanders Novum $A B$.

Roland, B., 2003. Intrinsic and Extrinsic Motivation. Review ofEconomics Studies, pp. $480-520$.

Usman Moh.Uzer. 2002. Menjadi Guru Profesional. Bandung; Remaja Rosda Karya, Bandung

Salim, Djohan. 2000. Musik Meningkatkan Intelegensi Manusia. Yogyakarta :Institute for Music Education Studies.

Tim Bina Karya Guru. 2000. Ilmu Pengetahuan Sosial untuk Sekolah Dasar 6. Erlangga: Jakarta

Tohid, H. \& Jabbari, M., 2012. The effects of motivation in education. Procedia Social and behavioral Science, pp. $820-823$.

Widodo, H., 2015. Potret Pendidikan di Indonesia dan Kesiapannya Dalam Menghadapi Masyarakat Ekonomi Asia (MEA). Cendekia, pp. 294 - 306. 